Tifani Radiatul Aulia, Hasbullah Malau I Efektivitas Kinerja Lembaga Pemberdayaan Masyarakat (LPM) dalam Pelaksanaan Pemberdayaan Masyarakat di Nagari Tanjung Balik Kecamatan X Koto Diatas Kabupaten Solok

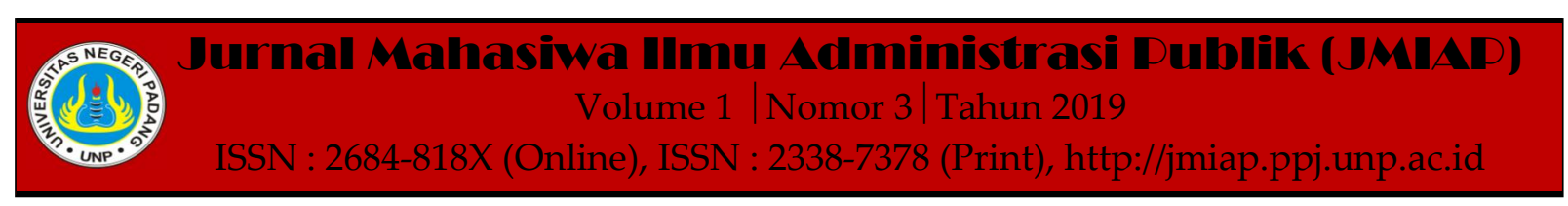

\title{
EFEKTIVITAS KINERJA LEMBAGA PEMBERDAYAAN MASYARAKAT (LPM) DALAM PELAKSANAAN PEMBERDAYAAN MASYARAKAT DI NAGARI TANJUNG BALIK KECAMATAN X KOTO DIATAS KABUPATEN SOLOK
}

\author{
Tifani Radiatul Aulia ${ }^{1(a)}$, Hasbullah Malau ${ }^{2(b)}$ \\ ${ }^{1}$ Jurusan Ilmu Administrasi Negara, Universitas Negeri Padang \\ ${ }^{2}$ Jurusan Ilmu Administrasi Negara, Universitas Negeri Padang \\ a)tifaniradiatul6@gmail.com, ${ }^{b)}$ hasbullahmalau@gmail.com
}

\begin{abstract}
This study aims to determine the effectiveness of the performance of community empowerment institutions in implementing community empowerment in Nagari Tanjung Balik. The research method that researchers use is a descriptive method with a qualitative approach. This research was conducted in the nagari Tanjung Balik District X Koto Diatas Solok Regency by selecting informants using purposive sampling techniques. Data were collected by interview, observation and documentation study. Data validity testing techniques with source triangulation. While the data analysis technique uses data collection techniques, data reduction, data presentation and conclusion drawing. The results of this study indicate that the effectiveness of the performance of community empowerment institutions in the implementation of empowerment is still not effective. This is because there are still problems in the LPM. The problems in this study are the quality of human resources in the LPM, lack of motivation for LPM members due to unclear wages, inadequate advice and infrastructure, coordination with other institutions not going well and low public awareness which causes the least participation of the community.
\end{abstract}

Keywords : Perfomance Effectiveness, Community Empowerment Institution, Community Empowerment

Corresponding author.Email.tifaniradiatul6@gmail.com,hasbullahmalau@gmail.com

How to cite this article. Aulia. T. Radiatul \& Malau. H. (2019). Efektivitas Kinerja Lembaga Pemberdayaan Masyarakat (LPM) dalam Pelaksanaan Pemberdayaan Masyarakat di Nagari Tanjung Balik Kecamatan X Koto Diatas Kabupaten Solok. Jurnal Mahasiwa Ilmu Administrasi Publik (JMIAP) Jurusan Ilmu Administrasi Negara Fakultas Ilmu Sosial Universitas Negeri Padang, Volume 1 (3), Hal. $42-50$.

http://jmiap.ppj.unp.ac.id

ISSN : 2684-818X (Online), ISSN : 2338-7378 (Print)

Copyright $\bigcirc 2019$. Published by Pusat Kajian-Pemberdayaan dan Pelayanan Masyarakat (PK-P2M) FIS UNP Padang 


\section{PENDAHULUAN}

Pemerintah ialah pihak yang paling bertanggung jawab dalam mengatasi persoalan yang dihadapi oleh negara. Hal tersebut mampu diatasi secara efektif dan efisien dengan adanya keikutsertaan masyarakat. Pemerintah bisa membentuk sebuah wadah organisasi yaitu salah satunya Lembaga Pemberdayaan Masyarakat. Pemberdayaan tersebut ialah upaya guna membina kompetensi masyarakat, mendorong, memupuk, membangun kesadaran terhadap potensi yang ada dan upaya untuk mengembangkan menjadi aksi yang nyata menurut Eddy Ch.Papilaya (Zubaedi, 2013). Lembaga Pemberdayaan Masyarakat dapat membantu masyarakat untuk ikut membantu pemerintah dalam mengatasi berbagai permasalahan. Banyaknya organisasi ditingkat daerah dapat membantu pemerintah dalam mengatasi permasalahan yang ada dimasyarakat. Lembaga Pemberdayaan Masyarakat ialah wadah yang dibentuk atas prakarsa masyarakat sebagai mitra pemerintahan dalam mengumpul serta mewujudkan keinginan dan kebutuhan masyarakat dalam pembangunan. LPM juga disebut lembaga masyarakat yang memiliki kedudukan sebagai teman kerja pemerintah di nagari dalam pembangunan ( Keputusan Presiden Nomor 49 Tahun 2001 ).

Fungsi pembentukan Lembaga Pemberdayaan Masyarakat yaitu untuk melibatkan masyarakat pada pembangunan di setiap bidang, menghubungkan antara kepentingan masyarakat bersama pemerintah serta pihak lain. Bergerak dalam membimbing persatuan dan kesatuan bangsa, meningkatkan rencana pemerintah dengan suara masyarakat, mengembangkan potensi ekonomi rakyat agar mampu menikmati hasil-hasil dari pembangunan, memperkokoh potensi masyarakat ikut bergotong-royong dalam kegiatan sosial dan penanggulangan bencana. Pada Undang-Undang Republik Indonesia
Nomor 32 Tahun 2004 tentang Pemerintahan Daerah pada Pasal 211 menyebutkan bahwa bisa dibuat organisasi masyarakat yang ditentukan dalam peraturan desa yang mengacu pada peraturan perundang-undangan, organisasi masyarakat bekerja dalam membantu pemerintah nagari dan merupakan rekan dalam kegiatan pemberdayaan masyarakat nagari.

Tujuan diadakan serta dibentuknya Lembaga Pemberdayaan Masyarakat (LPM) di Nagari diantaranya yaitu menciptakan kesadaran masyarakat pada kehidupan berbangsa dan bernegara didalam suatu wadah negara Kesatuan Republik Indonesia bedasarkan pancasila dan UUD 1945, menggerakkan partisipasi masyarakat pada perencanaan, pelaksanaan dan pengendalian pembangunan, serta meningkatkannya potensi di dalam masyarakat sebagai sumber daya manusia dan meningkatnya ekonomi masyarakat pada pengupayaan pemberantasan kemiskinan.

Keputusan Menteri Dalam Negeri Republik Indonesia mengenai Kader Pemberdayaan Masyarakat dalam Permendagri Nomor 7 Tahun 2007 disebutkan pada setiap kegiatan pengembangan, penyelenggaraan peran serta swadaya gotong royong masyarakat pada Nagari perlu diciptakan anggota Pemberdayaan Masyarakat. Anggota Pemberdayaan Masyarakat adalah mitra pemerintah Nagari yang dibutuhkan keterlibatan dan perananya pada kegiatan pemberdayaan masyarakat dan pembangunan partisipatif di Nagari.

Menurut keputusan diatas, Nagari Tanjung Balik Kecamatan X Koto Diatas turut membentuk Lembaga Pemberdayaan Masyarakat. Pembentukan LPM dilakukan untuk membantu kemajuan masyarakat Nagari. Namun, pada LPM tersebut ditemui beberapa permasalahan dalam pelaksanaan kegiatan pemberdayaan masyarakat yang 
menyebabkan tidak adanya kemajuan pada kinerja LPM. Padahal, masyarakat di Nagari Tanjung Balik sangat memerlukan adanya pemberdayaan. Kondisi perekonomian masyarakat di Nagari Tanjung Balik Kecamatan X Koto Diatas sendiri bisa dikatakan sedang. Masyarakat kurang memiliki kesadaran hidup karena mereka yang hanya memenuhi kebutuhan untuk hari ini saja tanpa memikirkan ataupun berusaha untuk memenuhi kebutuhan hari esok. Selain itu, masyarakat juga sangat tertutup akan ilmu yang mereka peroleh untuk kemajuan dan pengetahuan cara bertani. Jika ditinjau dari segi teknologi pertanian saat ini, cara bertani mereka sangat-sangat kurang sesuai. Oleh karena itu, perlu dilakukan pemberdayaan karena pada umumnya masyarakat di Nagari ini adalah petani.

\section{TINJAUAN PUSTAKA}

\section{Konsep Efektivitas}

Kata efektivitas berasal dari bahasa inggris yaitu effective yang berarti berhasil atau sesuatu yang dilakukan berhasil dengan baik. Kamus ilmiah popular mendefenisikan efektivitas sebagai ketetepatan penggunaan, hasil guna atau menunjang tujuan. Efektivitas berfokus pada outcome (hasil), program atau kegiatan yang dinilai efektif apabila output yang dihasilkan dapat memenuhi tujuan yang diharapkan.

Edi Sutrisno (2011:145) mengatakan bahwa efektif atau efektivitas dapat diartikan sebagai tingkat atau derajat pencapaian hasil yang diharapkan. Sedangkan konsep efektivitas menurut James I.Gibson (Harbani Pasolog, 2010:4) mengatakan bahwa efektivitas adalah pencapaian sasaran dari upaya bersama. Jika sasaran dan tujuan yang direncanakan sudah sesuai maka dapat dikatakan efektif, namun apabila sasaran dan tujuan tidak sesuai dengan yang direncanakan maka itu tidak efektif.

\section{Konsep Efektivitas Kinerja}

Efektivitas kinerja diartikan sebagai suatu kemampuan untuk memilih sasaran yang tepat sesuai dengan tujuan-tujuan yang telah ditetapkan dari awal. Pendapat ini didukung Danim (2004) yang mengatakan efektivitas kinerja kelompok, berkaitan dengan kemampuan anggotaanggota untuk memilih atau melakukan sesuatu yang tepat demi kepentingan bersama.

Efektivitas kinerja akan meningkat apabila seseorang memiliki keterampilan dan keahlian yang sesuai dengan tuntutan kerja. Efektivitas kinerja individu dapat diukur dari keterampilan kerja, peningkatan prestasi, kemampuan untuk beradaptasi, dan mampu menghadapi perubahan (Bass dan Daft, 1989).

Soeprihanto (2001) mengatakan efektivitas kinerja berkaitan erat dengan prestasi kerja seseorang. Efektivitas kinerja dan prestasi tidak hanya dinilai dari hasil secara fisik tetapi juga mencakup pelaksanaan kerja secara keseluruhan yang meliputi kemampuan kerja, hubungan kerja, disiplin kerja, prakarsa dan kepemimpinan. Kemampuan individu untuk melakukan pekerjaan sesuai dengan tujuan dan sasaran yang ditetapkan merupakan salah satu indikator kinerja yang efektif dan prestasi yang tinggi.

Dalam mengukur tingkat kinerja LPM tersendiri diungkapkan oleh Bagindo dan M. Ridwan (Irsa Yonanda. dkk, 2013: 7273) antara lain:

1) Mutu pekerjaan ialah bagaimana baik pekerjaan yang sudah dilaksanakan oleh karyawan dengan mempertimbagkan permasalahan berkaitan dengan kualitas pekerjaan.

2) Ketetapan waktu ialah bagaimana kecepatan dalam bekerja dengan tepatnya waktu pada volume pekerja ini terdapatnya unsur waktu yang 
berfungsi sebagai batas pencapaian suatu pekerjaan.

3) Pengetahuan dan inisiasi karyawan mengenai pekerjaan yaitu kemampuan karyawan dalam melaksanakan tugas dan mulai ikut melakukan hal-hal tanpa arahan spesifik dalam mengambil setiap langkah.

4) Sikap kerja merupakan sejauh mana semangat karyawan dalam pekerjaannya, apabila datang kondisi darurat dibutuhkan usaha yang lebih besar daripada sebelumnya.

\section{Konsep pemberdayaan Masyarakat}

Pemberdayaan berasal dari kata Daya atau Power. Dengan power yang dimiliki seseorang atau sekelompok orang diharapkan dapat mendayagunakan kekuatan yang dimiliki untuk mengakses informasi, teknologi, modal, mengembangkan keterampilan dalam menemukan solusi atas masalah kehidupan. Dengan demikian, pemberdayaan berkaitan dengan upaya perubahandalam struktur sosial masyarakat karena ada proses sharing power, peningkatan kemampuan dan penetapan kewenangan Siti Amanah \& Narni Fatmayanti (2014:1-2).

Pemberdayaan masyarakat merupakan upaya untuk meningkatkan kemampuan masyarakat agar mampu berdiri sendiri dengan keterampilan dan pengetahuan yang dimilikinya untuk mengatasi masalahmasalah mereka sendiri, meningkatkan kualitas hidup, mencapai kesejahteraan dan memperbaiki kedudukannya dalam masyarakat (Ristinura Indrika, 2013:13).

\section{METODE PENELITIAN}

Penelitian ini memakai metode deskriptif dengan pendekatan kualitatif yang bertempat di nagari Tanjung Balik Kecamatan X Koto Diatas Kabupaten Solok. Pemilihan informan pada penelitian ini memakai teknik purposive sampling. Sumber dan jenis data yang dipakai yaitu data sekunder dan data primer. Alat dan teknik pengumpulan data yang dipakai dalam penelitian ini adalah teknik observasi, wawancara dan studi dokumentasi. Uji keabsahan data dalam penelitian ini memakai teknik triangulasi sumber. Teknik analisis yang dipakai pada penelitian ini adalah teknik reduksi data, pengumpulan data, penyajian data, dan penarikan kesimpulan.

\section{HASIL DAN PEMBAHASAN}

\section{Efektivitas Kinerja Lembaga Pemberdayaan Masyarakat dalam Pemberdayaan Masyarakat di Nagari Tanjuang Balik Kabupaten Solok}

Tingkat efektivitas kinerja dapat dilihat berdasarkan yang diungkapkan oleh Bagindo dan M. Ridwan (dalam Irsa Yonanda 2013:72-73), bahwa beberapa indikator pengukur tingkat efektivitas kinerja tersebut yaitu :

\section{a) Mutu pekerjaan}

Berdasarkan hasil yang penulis temukan bahwa tingkat kualiatas sumber daya manusia atau anggota LPM di nagari tanjuang balik masih banyak dari SDM yang kurang berkualitas. Anggota LPM di nagari tanjuang balik banyak yang tidak memahami tugas dan fungsi mereka sendiri. Selain itu anggota LPM nagari Tanjuang Balik juga tidak mampu membina dan membimbing masyarakat serta mengajak masyarakat agar ikut pada kegiatan yang dilaksanakan LPM. Hal ini juga disebabkan karena proses perekrutan anggota dalam LPM nagari Tanjuang Balik hanya dilakukan berdasarkan kesukarelaan saja dan tidak berdasarkan peroses yang memeliki syarat tertentu seperti skill dan tingkat pendidikan atau sebagainya.

Temuan di atas relevan dengan teori yang disampaikan oleh prof dasman lanian dimana salah satu indikator dalam mengukur efektivitas kinerja yaitu mutu pekerjaan. Dimana mutu pekerjaan yang berarti kulaitas kerja anggota LPM yang masih belum berkualitas, dapat dikatakan 
Tifani Radiatul Aulia, Hasbullah Malau I Efektivitas Kinerja Lembaga Pemberdayaan Masyarakat (LPM) dalam Pelaksanaan Pemberdayaan Masyarakat di Nagari Tanjung Balik Kecamatan X Koto Diatas Kabupaten Solok

bahwa mutu pekerjaan atau efektivitas kinerja anggota LPM masih belum efektif.

b) Ketetapan waktu

Temuan yang penulis temukan bahwasanya dalam ketetapan waktu kinerja LPM nagari Tanjuang Balik masih belum dapat dikatakan efektif. Dalam ketepatan waktu, banyak anggoa LPM yang tidak tepat waktu datang dalam menghadiri setiap kegiatan LPM. Selain itu aggota LPM juga meiliki volume kerja yang tidak sesuai dengan seharusnya dan hasilnya pun tidak sesuai dengan volume kerja anggota LPM naagari Tanjuang Balik. Kegiatan yang dilaksanakan oleh LPM di nagari Tanjuang Balik juga dalam dua tahun terakhir banyak yang tidak berjalan. Dan pada tahun ketiga ini, LPM nagari Tanjuang Balik baru memulai kembali untuk mejalankan kegiatan-kegiatan pemberdayaan masyarakat di nagari Tanjuang Balik.

Temuan ini juga sesuai berdasarkan teori yang diungkapkan oleh Bagindo dan Ridwan bahwa ketetapan waktu merupakan salah satu indikator dalam mengukur efektivitas kinerja. Ketetapan waktu dijelaskan bagaimana kecepatan kerja dengan bagaimana ketetapan waktu, volume waktu yang berguna sebagai pengingat penyelesaikan suatu pekerjaan. Dan berdasarkan hasil temuan penulis diatas dapat dikatakan bahwa ketetapan waktu di LPM nagari Tanjuang Balik masih belum efektif.

c) Pengetahuan dan inisiatif pegawai mengenai pekerjaan

Pada hasil temuan penulis anggota LPM nagari Tanjuang Balik masih banyak yang kurang akan pengetahuan dan tidak berinisiatif dalam melaksanakan tugasnya. Anggota LPM tidak mengatahui apa tugas dan fungsinya karena kurangnya pengetahuan mereka mengenai LPM itu sendiri. Dalam pelaksanaan tugasnya para anggota LPM di nagari Tanjuang Balik juga tidak memiliki inisiantif ketika ankan pergi mengahdiri kegiatan LPM serta ketika melakukan tugasnya. Anggota LPM nagari Tanjuang Balik hanya bergerak ketika di arahkan atau diperintahkan saja.

Temuan ini juga sesuai dengan teori yang disampaikan Bagindo dan M. Ridwan (dalam Irsa Yonanda 2013:72-73) ini bahwa pengetahuan dan inisiatif menjadi indikator dalam mengukur tingkat keefektivitasan kinerja. Dilihat dari hasil kinerja LPM nagari Tanjuang Balik tidak berjalan maksimal dikarenakan pengetahuan dan inisatif yang rendah. Tidak kesanggupan para anggota LPM nagari Tanjuang Balik dalam menerima tanggung jawab dan melaksanakan hah-hal tanpa intruksi secara detail membuat kinerja LPM nagari Tanjung Balik ini masihlah belum efektif.

d) Sikap Kerja

Pada hasil temuan penulis, sikap kerja LPM Nagari Tanjung Balik banyak dari mereka yang tidak bersemangat untuk melaksanakan tugas mereka dalam pemberdayaan masyarakat. Hal tersebut diakui bahwa karena kurangnya motivasi anggota LPM seperti masalah upah/gaji. Kurangnya motivasi tersebut membuat anggota LPM Nagari Tanjung Balik memiliki sikap yang kurang bersemangat sehingga tidak adanya keefektifan dalam kinerja mereka.

Sesuai dengan teori yang diungkapkan oleh mo'ekjat (2002:5) dimana motivasi memiliki artian motif ialah suatu daya pendorong atau penyemangat melakukan sesuatu. Dapat dikatakan motivasi yaitu hal yang menimbulkan, menyalurkan dan mendorong perilaku manusia agar bekerja giat dan semangat, dikarenakan anggota LPM Nagari Tanjung Balik yang kurang memiliki motivasi, maka kinerja yang dihasilkan juga menjadi tidak efektif. 
Tifani Radiatul Aulia, Hasbullah Malau I Efektivitas Kinerja Lembaga Pemberdayaan Masyarakat (LPM) dalam Pelaksanaan Pemberdayaan Masyarakat di Nagari Tanjung Balik Kecamatan X Koto Diatas Kabupaten Solok

\section{Kendala yang dihadapi Lembaga Pemberdayaan Masyarakat dalam pelaksanaan Pemberdayaan Masyarakat di Nagari Tanjung Balik, Kecamatan X Koto Diatas Kabupaten Solok.}

Faktor-faktor atau kendala yang mempengaruhi kinerja terdiri dari faktor internal dan faktor eksternal yaitu menurut Mangkunegara dalam Nur Annisa (2006:103):

a) Internal

1) SDM yang kurang berkualitas Pada hasil temuan penulis, SDM di LPM Nagari Tanjung Balik menjadi kendala yang dihadapi dalam pemberdayaannya. SDM atau para anggota LPM nagari tanjung balik masih belum memahami, berpengetahuan tentang Tupoksi LPM itu sendiri, selain itu anggota LPM nagari Tanjung Balik juga masih belum mampu membina, membimbing serta menggerakkan masyarakat di dalam kegiatan pemberdayaan yang dilakukan oleh LPM Nagari Tanjung Balik. Werther dan Davis (1996) menyebutkan SDM ialah karyawan yang siap dan mampu dalam mencapai tujuan-tujuan organisasi. Jadi sesuai dengan teori diatas SDM harus siap, mampu dan siaga dalam pencapaian tujuan organisasi, sedangkan dimana SDM LPM Nagari Tanjung Balik masih belum mampu mencapai tujuan-tujuan dari LPM. Hal tersebut menjadi kendala yang dihadapi LPM sendiri.

2) Kurangnya Motivasi Anggota LPM Pada hasi temuan penulis, kurangnya motivasi anggota LPM nagari Tanjuang Balik menjadi kendala internal yang dihadapi oleh LPM dalam pelaksanaan pemberdayaan masyarakat. Anggota LPM tidak termotivasi karena tidak jelasnya gaji atau upah serta tunjangan yang mereka terima. Dikarenakan kurangnya kegiatan yang diadakan oleh LPM, juga karena kegiatan LPM ini dalam pemberdayaan masyarakat merupakan pekerjaan sosial diamana adanya kesukarelaan. Namun anggota LPM tersebut tetap memerlukan upah atau gaji dikarenakan untuk memenuhi kebutuhan keluarga mereka. Oleh sebab itu anggota LPM Nagari Tanjuang Balik tidak termotivasi dan lebih memillih melakukan pekerjaan mereka yang lain disamping menjadi anggota LPM tersebut yang lebih dapat memberikan mereka upah atau gaji yang jelas. Temuan ini juga sesuai dengan yang diungkapkan oleh Hasibuan (2016:103) bahwa setiap pegawai atau karyawan mengharapkan kompensasi (gaji/upah) dari prestasi yang diberikannya dalam mendukung faktor motivasi kerja. Ketika upah atau gaji yang diharapkan oleh seorang karyawan atau anggota LPM yang tidak jelas menyebabkan motivasi mereka dalam melaksanakan kegiatan pemberdayaan masyarakat menjadi tidak optimal.

3) Sarana dan prasarana yang belum memadai

Dalam hasil temuan penulis, kendala internal lainnya yang dihadapi oleh LPM Nagari Tanjuang Balik yaitu sarana dan prasaran yang belum memadai. Seperti dalam program tanam tebu yang dilaksanakan oleh LPM Nagari Tanjuang Balik ditemukan bahwa peralatan yang digunakan tidak mencukupi. Kegiatan yang dilakukan bersama masyarakat tersebut kekurangan cangkul dan sabit sehingga adanya masyarakat 
yang membawa peralatan dari rumah mereka masing-masing.

b) Eksternal

1) Rasa kesadaran dan partisipasi masyarakat yang masih rendah

Dari hasil temuan penulis, partisipasi masyarakat di Nagari Tanjuang Balik masih rendah masyarakat tidak tertarik unk mengikuti kegiatan yang diadakan oleh LPM Nagari Tanjung Balik dikarenakan rendahnya kesadaran masyarakat. Selain lemahnya pemahaman masyarakat mengenai LPM mereka juga susah untuk dapat menghadiri kegiatan LPM tersebut karena memiliki kegiatan lain. Temuan diatas sesuai dengan teori yang diungkapkan oleh Sudarwan Danim (1995:56) menyebutkan bahwa dalam pemberdayaan masyarakat terdapat tiga aktor penting yang turut dalamproses pemberdayaan salah satunya masyarakat. rendahnya tingkat partisipasi masyarakat di Nagari Tanjung Balik mengakibatkan tujuan pemberdayaan tersebut tidak tercapai.

2) Koordinasi LPM yang kurang baik Pada hasil temuan penulis, koordinasi LPM dengan pihak terkait diantaranya pemerintah nagari kurang baik. Adanya konflik antara ketua LPM dengan wali nagari membuat koordanasi diantara keduanya tidak berjalan baik. Hal tersebut juga menyebabkan tidak adanya pergerakn oleh LPM dalam melaksanakan kegiatan pemberdayaan dalam waktu yang lama.

Menurut Awaluddin Djamin dalam hasibuan (2011:86) menyebutkan koordinasi dapat diartikan sebagai suatu kerja sama antara lembaga, instansi, unit pada pelaksanaan tugas-tugas tertentu sehingga bisa saling mengisi, melengkapi dan membantu, jadi tanpa adanya koordinasi yang baik antara LPM dengan Pemerintah Nagari, maka tidak adanya saling membantu dan melengkapi sehingga pelaksanaan kegiatan pemeberdayaan masyarakat di Nagari Tanjung Balik tidak berjalan baik.

3) Kurangnya komunikasi LPM dengan masyarakat

Dari hasil temuan penulis hubungan antara LPM dengan masyarakat kurang terjalin, dikarenakan kurangnya komunikasi antara LPM dengan masyarakat yaitu tingkat sosialisasi LPM kemasyarakat Nagari Tanjung Balik yang jarang dilakukan oleh LPM. Dalam suatu pelaksanaan adapun faktor yang mempengaruhi menurut George $\mathrm{C}$. Edward III (AG. Subarsono, 2015:90) dimana salah satu faktornya adalah komunikasi, begitu juga pelaksanaan pemberdayaan masyarakat yang dilakukan LPM di Nagari Tanjung Balik dimana kekurangannya komunikasi antara LPM dengan masyarakat menjadi kendala mencapai tujuan dari pelaksanaan pemberdayaan Nagari Tanjung Balik.

Upaya yang dilakukan oleh Lembaga Pemberdayaan Masyarakat (LPM) dalam Pelaksanaan Pemberdayaan Masyarakat di Nagari tanjung Balik Kecamatan X Koto Diatas Kabupaten Solok

1) Pemberian Latihan Sumber Daya Manusia (SDM)

Menurut Moekijat (dalam Sutarto, 2012:9) secara garis besar pelatihan adalah 
guna meningkatkan keahlian agar pekerjaan dapat terselesaikan dengan lebih efektif dan cepat, Meningkatkan pengetahuan sehingga pekerjaan mampu diselesaikan secara dalam mengembangkan sikap agar menciptakan kemauan kerja sama.

Teori diatas sesuai dengan hasil temuan penulis di Nagari Tanjung Balik bahwa dalam mengupayakan peningkatan tingkat kualitas SDM di LPM, LPM mengadakan pelatihan berupa seminar-seminar dengan mendatangkan orang yang ahli dalam pemeberdayaan masyarakat. Dengan diadakan pelatihan tersebut diharapkan anggota LPM meningkatkan pengetahuan dan keterampilannya dalam bidang pemberdayaan sehingga dapat menerapkannya dalam pelaksanaan tugasnya dalam kegiatan yang diselenggarakan LPM Nagari Tanjung Balik.

\section{2) Meningkatkan Pemberian Sosialisasi} Vander Zande ( dalam Ihromi 2004:30 ) mengungkapka Sosialisasi merupakan proses interaksi sosial melalui dimana kita mengenal pola berpikir, berperasaan dan berperilaku agar mampu berperan aktif di masyarakat. sosialisasi dapat diartikan cara LPM berkomunikasi kepada masyarakat Nagari Tanjung Balik.

Berdasarkan teori diatas sesuai dengan temuan penulis bahwa LPM Nagari Tanjung Balik telah meningkatkan sosialisasi kepada masyarakat. LPM Nagari Tanjung Balik mengajak dan mengundang masyarakat untuk datang dalam kegiatan sosialisasi dengan peningkatan sosialisasi oleh LPM Nagari Tanjung Balik. Upaya tersebut di harapkan menumbuhkan dan meningkatkan rasa kesadaran masyarakat dan komunikasi yang terjalin antara LPM dengan masyarakat menjadi harmonis dan pelaksanaan kegiatan pemberdayaan berjalan lebih efektif.

3) Mengadakan Pertemuan antara LPM dengan SKPD terkait
Pada temuan penulis, LPM Nagari Tanjung Balik mengadakan pertemuan dengan pemerintah nagari dan Lembaga/ Instansi terkait untuk meningkatkan koordinasi yang sebelumnya tidak berjalan baik.

Seperti yang telah diungkapkan oleh Sondang P Siagian (2010:110) merupakan koordinasi berhubungan dengan pengaturan tata hubungan dari upaya bersama guna memperoleh keserasian tindakan dalam upaya mencapai tujuan bersama sehingga pembagian kerja dan berbagai kelompok atau orang bisa tersusun kesatu kebulatan yang berintegrasi dengan seefisien mungkin. Dikatakan dengan adanya pertemuan bersama dengan LPM Nagari Tanjung Balik kembali terjalin hubungan yang baik sehingga kegiatan pemberdayaan yang diselenggarakan berjalan dengan baik.

\section{PENUTUP}

Kesimpulan yang penulis temukan diantaranya:

1. Kinerja LPM dalam pelaksanaan pemberdayaan masyarakat di Nagari Tanjung Balik masih belum efektif. Berdasarkan indikator dalam pengukuran efektivitas kinerja yang diungkapkan oleh Bagindo dan M. Ridwan (dalam Irsa Yonanda 2013:72-73).

2. Kendala yang ditemukan oleh LPM dalam pelaksanaan pemberdayaan masyarakat di Nagari Tanjung Balik diantaranya kendala internal yaitu SDM LPM Nagari Tanjung Balik yang kurang berkualitas, kurangnya motivasi anggota LPM, sarana dan prasarana yang kurang memadai. Dari eksternal kendala yang ditemukan yaitu partisipasi dan kesadaran masyarakat masih rendah, komunikasi antar LPM dan masyarakat belum baik dan koordinasi antara LPM dengan SKPD terkait tidak berjalan baik. 
Tifani Radiatul Aulia, Hasbullah Malau I Efektivitas Kinerja Lembaga Pemberdayaan Masyarakat (LPM) dalam Pelaksanaan Pemberdayaan Masyarakat di Nagari Tanjung Balik Kecamatan X Koto Diatas Kabupaten Solok

3. Upaya yang telah dilakukan LPM dalam pelaksanaan pemberdayaan masyarakat di Nagari Tanjung Balik yaitu pemberian pelatihan terhadap anggota LPM, peningkatan sosialisasi masyarakat dan mengadakan pertemuan bersama LPM, Pemerintah Nagari dan SKPD terkait.

\section{DAFTAR KEPUSTAKAAN}

AG. Subarsono. 2015. Kebijakan publik : konsep teori, dan aplikas. Yogyakarta. Pustaka pelajar.

Harbani Pasolong. 2010. Teori Administrasi Publik. Bandung : Alfabeta.

Moekijat, 2002, Dasar-dasar Motivasi, Pionis Jaya, Jakarta.

Sondang P. Siagian. 2010. Manajemen Sumber Daya Manusia, Bumi Aksara, Jakarta.

Sugiyono. 2011. Metode Penelitian Administrasi. Bandung: Alfabeta.

Sugiyono. 2012. Metode Penelitian Kuantitatif Kualitatif dan R\&D. Bandung: Alfabeta.

Sudarwan Danim, 1995. Transformasi Sumber Daya Manusia. Jakarta: Bumi Aksara.

Sutarto.2012. Dasar-dasar Kepemimpinan Administrasi. GMUP.

T.O.Ihromi. 2004. Bunga Rampai Sosiologi Keluarga. Jakarta: Buku Obor. Halaman: 30.

Werther, William B. \& Keith Davis. 1996. Human Resources And Personal Management. Edisi kelima. New York: McGraw-Hill.

Undang-Undang Republik Indonesia Nomor 32 Tahun 2004
Surat Keputusan Dewan Pimpinan Cabang Lembaga Pemberdayaan Masyarakat Kecamatan X Koto Diatas.

Keputusan Presiden Nomor 49 Tahun 2001 tentang Penataan Lembaga Ketahanan Masyarakat Desa atau Sebutan Lainnya.

Keputusan Mendagri No 7 Tahun 2007 tentang Kader Pemberdayaan masyarakat.

Keputusan Bupati Solok Nomor 12 Tahun 2003 Tentang Pedoman Umum Pembentukan Lembaga Pemberdayaan Masyarakat Nagari dalam Kabupaten Solok.

Irsa Yonanda. 2013. Efektivitas Pelayanan Izin Mendirikan Bangunan ( IMB ) dalam sektor industri Pariwisata di Kota Batu . Jurnal Administrasi Publik .Vol 1 No. 1 2013. Hal. 72-73. 